\title{
An efficient synthesis of highly substituted indanones and chalcones promoted by superacid $\dagger$
}

Cite this: RSC Adv., 2014, 4, 26662

\author{
Amrita Das, Alavala Gopi Krishna Reddy, Jonnada Krishna and Gedu Satyanarayana*
}

Received 1st April 2014

Accepted 6th June 2014

DOI: 10.1039/c4ra04763j

www.rsc.org/advances

A superacid promoted one-pot process for the efficient synthesis of indanones is presented. This process enabled the formation of a dual C-C bond between aryl isopropyl ketones and benzaldehydes. Interestingly, when the reaction was performed between acetophenones and benzaldehydes, it was impeded just after the aldol condensation and resulted in the corresponding chalcones.

Organic synthesis in a one-pot procedure is an indispensible technique due to its advantage of constructing more than one bond without the need to isolate the intermediate species. Therefore, those techniques that enable the formation of $\mathrm{C}-\mathrm{C}$ bonds in a single step, particularly, for the synthesis of<smiles>COc1cc2c(cc1OC)C(c1ccc3c(c1)OCO3)=C(C)C2=O</smiles>
neo-lignin<smiles>Cc1cc2c(c(C)c1CCO)CC(C)(C)C2=O</smiles>

alcyopterosin $\mathrm{N}$<smiles>O=C1c2cc(O)cc(O)c2[C@H](c2cc(O)cc(O)c2)[C@H]1c1ccc(O)cc1</smiles>

pauciflorol $\mathrm{F}$<smiles>Cc1c2c(c(Cl)c(Cl)c1OCC(=O)O)C(=O)[C@@](C)(c1ccccc1)C2</smiles>

$(+)$-indacrinone
Fig. 1 Representative examples for indanone based drugs and natural products.

Indian Institute of Technology (IIT) Hyderabad, Ordnance Factory Estate Campus, Yeddumailaram - 502 205, Medak District, Andhra Pradesh, India. E-mail: gvsatya@iith.ac.in; Fax: +91(40) 23016032

$\dagger$ Electronic supplementary information (ESI) available. See DOI: 10.1039/c4ra04763j carbocyclic compounds are of significant importance. Because many such carbocyclic systems are present as core structure in many natural products of biological relevance. In this regard, among many classical $\mathrm{C}-\mathrm{C}$ bond forming reactions, FriedelCrafts reaction is treated as one of the best method for either alkylation or acylation discovered by Friedel and Crafts in $1877 .{ }^{1}$ Remarkably, in past few decades this reaction has been extensively applied in the field of organic synthesis under Brønsted/ Lewis acidic conditions. ${ }^{2-4}$ Significantly, the Friedel-Crafts cyclization became an useful method for the synthesis of cyclic systems via single or multiple $\mathrm{C}-\mathrm{C}$ bonds formation. ${ }^{5}$

Table 1 Optimization of reaction conditions for the synthesis of indanone $3 c$

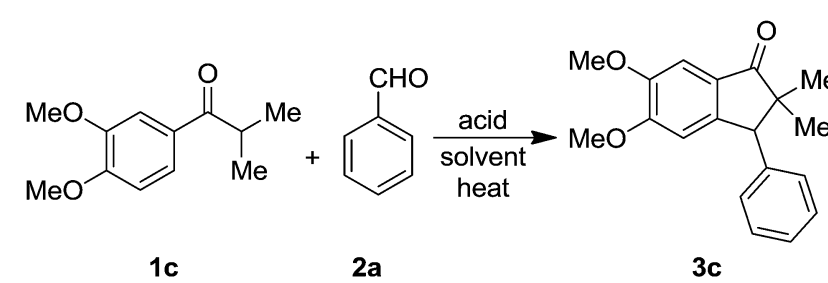

\begin{tabular}{|c|c|c|c|c|c|}
\hline Entry & $\begin{array}{l}\text { Acid } \\
\text { (equiv.) }\end{array}$ & $\begin{array}{l}\text { Solvent } \\
(\mathrm{mL})\end{array}$ & $\begin{array}{l}\text { Temp. } \\
\left({ }^{\circ} \mathrm{C}\right)\end{array}$ & $\begin{array}{l}\text { Time } \\
\text { (h) }\end{array}$ & $\begin{array}{l}\text { Yield }^{a} \\
(\%)\end{array}$ \\
\hline 1 & TFA (5) & DCE (2) & 50 & 12 & - \\
\hline 2 & TFA & TFA (2) & 50 & 12 & - \\
\hline 3 & TfOH (3) & DCE (2) & r.t. & 24 & 10 \\
\hline 4 & TfOH (5) & DCE (2) & r.t. & 24 & 30 \\
\hline $5^{b}$ & TfOH (3) & DCE (2) & 50 & 36 & 57 \\
\hline 6 & TfOH (5) & Benzene (2) & r.t. & 24 & - \\
\hline 7 & TfOH (5) & $\mathrm{CHCl}_{3}(2)$ & 50 & 24 & 50 \\
\hline 8 & TfOH (5) & DCE (2) & 50 & 24 & 85 \\
\hline 9 & $\mathrm{H}_{2} \mathrm{SO}_{4}(5)$ & DCE (2) & 50 & 16 & 60 \\
\hline 10 & $p$-TSA (3) & DCE (2) & 50 & 16 & - \\
\hline 11 & $\mathrm{FeCl}_{3}(3)$ & DCE (2) & 50 & 16 & - \\
\hline $12^{b}$ & $\mathrm{AlCl}_{3}(3)$ & DCE (2) & 50 & 36 & 61 \\
\hline
\end{tabular}

${ }^{a}$ Isolated yields of the pure products. ${ }^{b}$ yield calculated based on the recovery of starting material. 
Notably, the superelectrophiles (more reactive intermediate species) concept was introduced by Olah et al. ${ }^{6}$ which has been employed to build ring systems efficiently. ${ }^{3 b}$ As a part of our ongoing research interests on domino/sequential domino onepot transformations, ${ }^{7}$ recently, we have reported the synthesis of indanones using simple cinnamate esters via dual $\mathrm{C}-\mathrm{C}$ bond formation promoted by superacid. ${ }^{8}$ Also, very recently, we have developed mild method for the controlled formation of $\beta$-diaryl esters without the subsequent intramolecular acylation to give the indanones, via Friedel-Crafts Michael addition on cinnamate esters as key step for the synthesis of chromans. ${ }^{9}$ Indanones are ubiquitous systems that are present in many natural products, which show good range of biological activities as well as in a variety of drug candidates. Representative examples of such compounds include neo-lignin, ${ }^{\mathbf{1 0}}$ pauciflorol $\mathrm{F},{ }^{\mathbf{1 1}}$ alcyopterosin $\mathrm{N},{ }^{\mathbf{1 2}}$ and indacrinone $\mathrm{1}^{\mathbf{1 3}}$ (Fig. 1).
Because of the importance of indanone core, various acid mediated approaches have been reported on their synthesis. ${ }^{\mathbf{1 4}}$ With this background, we envisaged that it would be feasible to generate enol selectively from aryl alkyl ketone under acidic reaction conditions. Thus the so formed enol of the ketone would act as a nucleophile and attack on the electrophilic aldehyde group in intermolecular fashion to give the $\beta$-hydroxy ketone intermediate which in turn is liable for subsequent intramolecular Friedel-Crafts alkylation to furnish the target indanones. Though, it can be realized that the intramolecular Friedel-Crafts alkylation will not be much favourable with an aromatic ring directly connected to a deactivating group (carbonyl), the idea behind this aim is based on the use of heating conditions in the presence of acid that may overcome such hurdles. Herein, we present an efficient one-pot method for the synthesis of highly substituted indanones via dual $\mathrm{C}-\mathrm{C}$ bond formation promoted by superacid (triflic acid). On the

Table 2 Scope of superacid mediated one-pot formation of indanones 3 from various ketones $1^{a}$<smiles>[R][R]1ccccc1C=O</smiles>

1

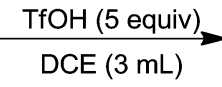

heat, $24 \mathrm{~h}$<smiles>[R]c1ccccc1C1C2=C(C=C[R1]C=C2)C(=O)C1(C)C</smiles>

3<smiles>CC1(C)C(=O)c2ccccc2C1c1ccccc1</smiles>

$3 a(50 \%)^{b}$<smiles>COc1cc2c(cc1OC)C(c1ccc(Br)cc1)C(C)(C)C2=O</smiles>

3 e $(66 \%)$<smiles>COc1cc2c(c(OC)c1OC)C(c1ccccc1)C(C)(C)C2=O</smiles>

$3 \mathbf{i}(86 \%)$<smiles>CC1(C)C(=O)c2ccccc2C1c1ccc(Cl)cc1</smiles>

3b $(54 \%)^{b}$<smiles>COc1ccc(C2c3cc(OC)c(OC)cc3C(=O)C2(C)C)cc1</smiles>

$3 f(83 \%)$<smiles>COc1cc2c(c(OC)c1OC)C(c1ccc(Cl)cc1)C(C)(C)C2=O</smiles>

3j (64\%)<smiles>COc1cc2c(cc1OC)C(c1ccccc1)C(C)(C)C2=O</smiles>

$3 c(85 \%)$<smiles>COc1ccc(C2c3cc(OC)c(OC)cc3C(=O)C2(C)C)cc1OC</smiles>

$3 g(78 \%)$<smiles>COc1ccc(C2c3c(cc(OC)c(OC)c3OC)C(=O)C2(C)C)cc1</smiles>

3k $(76 \%)$<smiles>COc1cc2c(cc1OC)C(c1ccc(Cl)cc1)C(C)(C)C2=O</smiles>

3d (65\%)<smiles>COc1cc2c(cc1OC)C(c1ccc([N+](=O)[O-])cc1)C(C)(C)C2=O</smiles>

$3 h(---)^{c}$

\footnotetext{
${ }^{a}$ One-pot reaction conditions for the formation of indanones 3: ketones 1 ( $\left.0.25 \mathrm{mmol}\right)$, aldehydes 2 (0.50 mmol, 2 equiv.), TfOH (1.25 mmol, 5 equiv.) and DCE $(1.5 \mathrm{~mL})$ at $80{ }^{\circ} \mathrm{C}$ for $48 \mathrm{~h}$ for the formation of indanones $3 \mathbf{a} \& \mathbf{3 b}$ and at $50{ }^{\circ} \mathrm{C}$ for $24 \mathrm{~h}$ for other indanones $3 \mathbf{c}-3 \mathbf{k}$ formation. Yields in the parentheses are isolated yields of chromatographically pure products. ${ }^{b}$ Yields based on the recovery of the starting material 1a.

${ }^{c}$ The reaction furnished neither the product nor the recovery of the starting material.
} 
Table 3 Superacid mediated indanones 4 \& $4^{\prime}$ formation from the ketone $1 \mathrm{~b}$



other hand, we have noticed that the reaction between the acetophenones and benzaldehydes, impeded after aldol condensation and gave the corresponding chalcones as the end products.

The required aryl isopropyl ketones for this study, were synthesized from the corresponding benzaldehydes using standard isopropyl Grignard addition and oxidation protocol (see, ESI $\dagger$ ). To find out the best optimized reaction conditions, the ketone 1c was chosen as model and reacted with the benzaldehyde $2 \mathbf{a}$ under different reaction conditions in the presence of acid as promoting agent and the results are summarized in Table 1 . Thus, the reactions of $\mathbf{1 c}$ with TFA either as reagent or
Table 4 Scope of superacid promoted chalcones 6 formation by aldol condensation from a variety of acetophenones $5^{a}$

<smiles>O=C(/C=C/c1ccccc1)c1ccccc1</smiles><smiles>O=C(/C=C/c1ccc(F)cc1)c1ccccc1</smiles><smiles>C[C@H](OC(=O)/C=C/c1ccc(Cl)cc1)C(C)(C)C</smiles><smiles>O=C(/C=C/c1ccc(Br)cc1)c1ccccc1</smiles><smiles>CC(C)(C)OC(C)(C)C</smiles>

6d $(94 \%)$<smiles>O=C(/C=C/c1ccccc1)c1ccc(Br)cc1</smiles><smiles>O=C(/C=C/c1ccc(Cl)cc1)c1ccc(Cl)cc1</smiles><smiles>COc1ccc(C(=O)/C=C/c2ccccc2)cc1</smiles>

$6 \mathbf{i}(82 \%)$<smiles>O=C(/C=C/c1ccc(Cl)cc1)c1ccc(Br)cc1</smiles>

${ }^{a}$ Reaction conditions for the formation of chalcones 6: ketones 5 (0.50 mmol), aldehydes 2 (1.0 mmol, 2 equiv.), TfOH ( $2.5 \mathrm{mmol}, 5$ equiv.) and DCE $(1.5 \mathrm{~mL})$ at $50{ }^{\circ} \mathrm{C}$ for $24 \mathrm{~h}$ for the formation of chalcones $6 \mathrm{a}-6 \mathbf{i}$. Yields in the parentheses are isolated yields of chromatographically pure products.

as the reaction medium at $50{ }^{\circ} \mathrm{C}$ were not clean (Table 1 , entries $1 \& 2$ ). On the other hand, treatment of $1 \mathrm{c}$ with superacid (triflic acid) in DCE at ambient temperature, furnished the product $3 \mathbf{c}$, albeit in poor yield (30\%) along with the recovery of the starting material 1c (Table 1, entry 4). However, when benzene was used as the solvent, the reaction was not clean (Table 1 , entry 6). Interestingly, the reaction in hot $\mathrm{CHCl}_{3}$, improved the product $3 \mathbf{c}$ yield (50\%, Table 1 , entry 7$)$. Gratifyingly, treatment of $1 \mathrm{c}$ in DCE at $50{ }^{\circ} \mathrm{C}$, was found to be the best and furnished $3 \mathrm{c}$ as an exclusive product in good yield (85\%, Table 1 entry 8). Use of concentrated $\mathrm{H}_{2} \mathrm{SO}_{4}$ also proved to be good and gave the product $3 \mathrm{c}$ in $70 \%$ yield (Table 1 , entry 9 ). On the other hand, the reaction with $p$-TSA, led to the total recovery of starting material 1c (Table 1, entry 10). On the other hand, use of other 

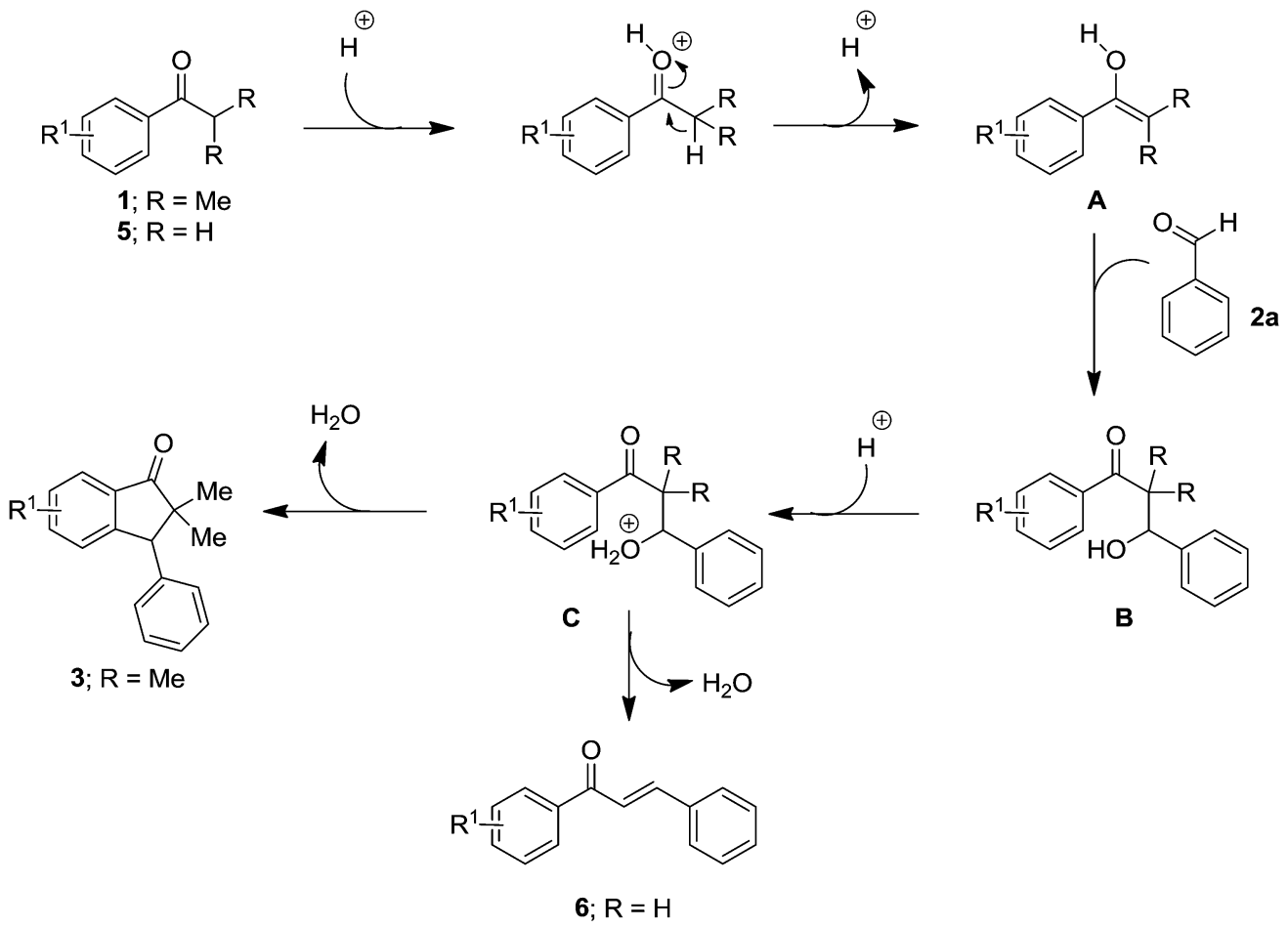

3; $\mathrm{R}=\mathrm{Me}$

Scheme 1 Possible reaction mechanism for the formation of indanone 3 and chalcone 6 .

Lewis acid $\left(\mathrm{FeCl}_{3}\right)$, led to unclear reaction mixtures (Table 1, entry 11). Also the use of Lewis acid $\mathrm{AlCl}_{3}$ at $50{ }^{\circ} \mathrm{C}$ resulted into the product $3 \mathrm{c}$ in $61 \%$ yield (Table 1 , entry 12 ).

Among all screened reaction conditions, the entry 8 of Table 1 turned out to be the best with respect to the yield of the product 3c. Therefore, these conditions were applied to the other systems 1a-1d to check the scope and limitations of the method. Gratifyingly, it was proved to be amenable and furnished the corresponding indanones $\mathbf{3 a} \mathbf{a}-\mathbf{3} \mathbf{j}$ with dense functionality on either of the aromatic rings, in good yields as shown in Table 2. It is worth mentioning that the reaction was smooth with electron rich aromatic ring of the ketones $\mathbf{1 b} \mathbf{b}-\mathbf{1 d}$. Whereas, in case of simple aromatic ketones 1a the reaction was found to be slow, as anticipated reaction rate depends on the electron rich nature of the aromatic ring. However, the reaction was successful by raising temperature from $50{ }^{\circ} \mathrm{C}$ to $80^{\circ} \mathrm{C}$, albeit in moderate yields of the products $\mathbf{3 a}$ and $\mathbf{3 b}$ (Table 2). While, further increasing the triflic acid amount (10 equivalents), led to the unclear reaction mixture. In general, the reaction was smooth for benzaldehydes 2 with simple to electron rich aromatic rings except 3,4,5-trimethoxybenzaldehyde $2 \mathrm{~g}$. In case of 3,4,5-trimethoxybenzaldehyde $2 \mathrm{~g}$, simple mono demethylation was observed from a para-methoxy group to the aldehyde group. The reaction was not clean with electron deficient para-nitrobenzaldehyde $\mathbf{2 h}$, where, neither the product nor the corresponding starting material was isolated.

While, the reaction with 3-anisyl isopropyl ketone $\mathbf{1 b}$ furnished the regioisomeric mixture of indanones $4 \& 4^{\prime}$ in almost $4: 1$ ratios, in which, as expected, the major isomer was the one where cyclization occurred at para-position to the methoxy group and the results are as summarized in the Table 3.
To further check the scope and generality of the method, we have attempted the reaction between acetophenones $\mathbf{5}$ and benzaldehydes 2 as well. Surprisingly, the reaction was impeded after the aldol condensation without subsequent cyclization (Table 4). This may be due to thermodynamic stability of enone systems. Moreover, to check the generality of the process, we have explored the reaction between different acetophenones 5 and benzaldehydes 2 . Gratifyingly, the reaction was found to be quite successful and gave the corresponding chalcones 6 in very good to excellent yields as shown in Table 4 .

The possible reaction mechanism for the formation of indanones 3 and chalcones 6 is outlined in Scheme 1. Initially, the acid can activate ketone through protonation to the carbonyl oxygen and yields the corresponding enol A. Nucleophilic attack of the enol $\mathbf{A}$ to the electrophilic aldehyde carbon furnishes the $\beta$-hydroxy ketone intermediate $\mathbf{B}$. Since the $\beta$ hydroxy ketone intermediate $\mathbf{B}$ can be liable for intramolecular Friedel-Crafts alkylation in the presence of acid, it triggers to the cyclization through the intermediate $\mathbf{C}$ and generates the final indanone product 3. Similarly, in case of acetophenones, it yields the corresponding $\beta$-hydroxy ketone intermediate $\mathbf{B}$. However, because of the availability of $\beta$-hydrogen for hydroxyl group it prefers dehydration than cyclization and furnishes the chalcone 6 products.

\section{Conclusions}

In summary, we have developed an efficient one-pot method for the synthesis of highly substituted indanones via dual $\mathrm{C}-\mathrm{C}$ bond formation promoted by superacid. Significantly, these 
indanone systems are ubiquitous units that are present in drugs and many biologically active natural products. Interestingly, when acetophenones were treated with benzaldehydes in the presence of super acid, the reaction was impeded after aldol condensation and furnished the chalcones. Further, applications of this method to different structurally important carbocyclic compounds are under progress.

\section{Acknowledgements}

Financial support by the Council of Scientific and Industrial Research [(CSIR), 02(0018)/11/EMR-II], New Delhi, is gratefully acknowledged. A. G. K. R. and J. K. thank CSIR, New Delhi, for the award of research fellowship.

\section{Notes and references}

1 C. Friedel and J. M. Crafts, Compt. Rend., 1877, 84, 1450.

2 For reviews, see: (a) S. Kobayashi, M. Sugiura, H. Kitagawa and W. W.-L. Lam, Chem. Rev., 2002, 102, 2227; (b) T. B. Poulsen and K. A. Jørgensen, Chem. Rev., 2008, 108, 2903; (c) J. M. Sartori and R. Maggi, Chem. Rev., 2011, 111, 181; (d) M. Rueping and B. J. Nachtsheim, Beilstein J. Org. Chem., 2010, 6, 1-24; (e) M. Shi, J.-M. Lu, Y. Wei and L.-X. Shao, Acc. Chem. Res., 2012, 45, 641.

3 (a) P. H. Gore and G. A. Olah, in Friedel-Crafts and Related Reactions, John Wiley and Sons, London, 1964, Part 1 vol. III, p. 1; (b) G. A. Olah and D. A. Klumpp, Superelectrophiles and Their Chemistry, Wiley, New York, 2008.

4 (a) K. K. S. Sai, M. J. Tokarz, A. P. Malunchuk, C. Zheng, T. M. Gilbert and D. A. Klumpp, J. Am. Chem. Soc., 2008, 130, 14388; (b) Y. Zhang, M. R. Sheets, E. K. Raja, K. N. Boblak and D. A. Klumpp, J. Am. Chem. Soc., 2011, 133, 8467; (c) D. A. Evans and K. R. Fandrick, Org. Lett., 2006, 8, 2249; (d) M. D. Rose, M. P. Cassidy, P. Rashatasakhon and A. Padwa, J. Org. Chem., 2007, 72, 538; (e) Y.-C. Wu, L. Liu, Y.-L. Liu, D. Wang and Y.-J. Chen, J. Org. Chem., 2007, 72, 9383.

5 (a) T. Suzuki, T. Ohwada and K. Shudo, J. Am. Chem. Soc., 1997, 119, 6774; (b) T. Ohwada, T. Suzuki and K. Shudo, J. Am. Chem. Soc., 1998, 120, 4629; (c) H. Kurouchi, H. Sugimoto, Y. Otani and T. Ohwada, J. Am. Chem. Soc., 2010, 132, 807; (d) H. M. Colquhoun, D. F. Lewis and D. J. Williams, Org. Lett., 2001, 3, 2337; (e) E. Fillion and D. Fishlock, Org. Lett., 2003, 5, 4653; $(f)$ Q. Wang and A. Padwa, Org. Lett., 2006, 8, 601; (g) S. Chassaing, M. Kumarraja, P. Pale and J. Sommer, Org. Lett., 2007, 9, 3889; (h) A. Saito, M. Umakoshi, N. Yagyu and Y. Hanzawa, Org. Lett., 2008, 10, 1783; (i) S. Tang, Y. Xu, J. He, Y. He, J. Zheng, X. Pan and X. She, Org. Lett., 2008, 10, 1855; (j) C. O. Kangani and B. W. Day, Org. Lett., 2008, 10, 2645; (k) K. Kim and I. Kim, Org. Lett., 2010, 12, 5314; (l) R. K. Chinnagolla and M. Jeganmohan, Org. Lett., 2012, 14, 5246; $(m)$ D. Eom, S. Park, Y. Park, T. Ryu and P. H. Lee, Org. Lett., 2012, 14, 5392; (n) D. A. Klumpp, D. N. Baek, G. K. S. Prakash and G. A. Olah, J. Org. Chem., 1997, 62, 6666; (o) R. Rendy, Y. Zhang, A. McElrea, A. Gomez and
D. A. Klumpp, J. Org. Chem., 2004, 69, 2340; (p) S. S. Bhar and M. M. V. Ramana, J. Org. Chem., 2004, 69, 8935; (q) G. B. Womack, J. G. Angeles, V. E. Fanelli and C. A. Heyer, J. Org. Chem., 2007, 72, 7046; (r) K. K. S. Sai, P. M. Esteves, E. T. D. Penha and D. A. Klumpp, J. Org. Chem., 2008, 73, 6506; (s) G. K. S. Prakash, F. Paknia, H. Vaghoo, G. Rasul, T. Mathew and G. A. Olah, J. Org. Chem., 2010, 75, 2219; $(t)$ E. K. Raja, D. J. DeSchepper, S. O. N. Lill and D. A. Klumpp, J. Org. Chem., 2012, 77, 5788; (u) Y. L. Choi, B. T. Kim and J.-N. Heo, J. Org. Chem., 2012, 77, 8762; (v) S. J. Mahoney, D. T. Moon, J. Hollinger and E. Fillion, Tetrahedron Lett., 2009, 50, 4706; (w) H. Aikawa, S. Tago, K. Umetsu, N. Haginiwa and N. Asao, Tetrahedron, 2009, 65, 1774.

6 G. A. Olah, A. Germain, H. C. Lin and D. A. Forsyth, J. Am. Chem. Soc., 1975, 97, 2928.

7 (a) A. G. K. Reddy and G. Satyanarayana, Tetrahedron, 2012, 68, 8003; (b) L. Mahendar, J. Krishna, A. G. K. Reddy, B. V. Ramulu and G. Satyanarayana, Org. Lett., 2012, 14, 628; (c) A. G. K. Reddy, J. Krishna and G. Satyanarayana, Tetrahedron Lett., 2012, 53, 5635; (d) A. G. K. Reddy, J. Krishna and G. Satyanarayana, Tetrahedron, 2013, 69, 10098; (e) L. Mahendar and G. Satyanarayana, J. Org. Chem., 2014, 79, 2059; (f) J. Krishna, A. G. K. Reddy and G. Satyanarayana, Synlett, 2013, 24, 967; $(g)$ J. Krishna, A. G. K. Reddy and G. Satyanarayana, Tetrahedron Lett., 2014, 55, 861.

8 B. V. Ramulu, A. G. K. Reddy and G. Satyanarayana, Synlett, 2013, 24, 868.

9 B. Suchand, J. Krishna, K. Mritunjoy and G. Satyanarayana, RSC Adv., 2014, 4, 13941.

10 (a) L. M. X. Lopes, M. Yoshida and O. R. Gottlieb, Phytochemistry, 1984, 23, 2021; (b) D. C. Harrowven, N. A. Newman and C. A. Knight, Tetrahedron Lett., 1998, 39, 6757.

11 T. Ito, T. Tanaka, M. Iinuma, K.-i. Nakaya, Y. Takahashi, R. Sawa, J. Murata and D. Darnaedi, J. Nat. Prod., 2004, 67, 932.

12 J. A. Palermo, M. F. Rodriguez Brasco, C. Spagnuolo and A. M. Seldes, J. Org. Chem., 2000, 65, 4482.

13 (a) U.-H. Dolling, P. Davis and E. J. J. Grabowski, J. Am. Chem. Soc., 1984, 106, 446; (b) S. J. deSolms, O. W. Woltersdorf Jr and E. J. Cragoe Jr, J. Med. Chem., 1978, 21, 437.

14 (a) D.-M. Cui, C. Zhang, M. Kawamura and S. Shimada, Tetrahedron Lett., 2004, 45, 1741; (b) E. Fillion, D. Fishlock, A. Wilsily and J. M. Goll, J. Org. Chem., 2005, 70, 1316; (c) M. B. Floyd and G. A. Allen Jr, J. Org. Chem., 1970, 35, 2647; (d) A. V. Vasilyev, S. Walspurger, P. Pale and J. Sommer, Tetrahedron Lett., 2004, 45, 3379; (e) N. J. Lawrence, E. M. S. Armitage, B. Greedy, D. Cook, S. Ducki and A. T. McGown, Tetrahedron Lett., 2006, 47, 1637; (f) W. Yin, Y. Ma, J. Xu and Y. Zhao, J. Org. Chem., 2006, 71, 4312; (g) J. Petrignet, T. Roisnel and R. Grée, Chem.-Eur. J., 2007, 13, 7374; (h) L. Liu, L. Wei, Y. Lu and J. Zhang, Chem.-Eur. J., 2010, 16, 11813; (i) P. Dubé and F. D. Toste, J. Am. Chem. Soc., 2006, 128, 12062; (j) D. H. Dethe and G. Murhade, Org. Lett., 2013, 15, 429. 